\title{
Revolution and Restoration: The Revolution of Quito (Ecuador) Within the Independence Process of Latin America
}

\author{
Juan J. Paz-y-Miño Cepedaa
}

\begin{abstract}
The Revolution of Quito (1808-1812) in many aspects pioneered the way during the Latin American independence process. After the independence of Haiti (1804) and at its initial stage, the Sovereign Junta in Quito, founded in 1809, took action together with the revolutionary movements of Chuquisaca and La Paz. Controlled, its members persecuted and finally killed, the Revolution of Quito passed from a loyalty to an independence movement which resulted in the creation of the new State of Quito. The defeat of the Revolution of Quito restored the old regime. In the middle of this process, the threat of the Holy Alliance, which was born at the Congress of Vienna (1814-1815), has particular significance for Quito and Latin America as it was the third attempt of a Spanish conquest. The celebrations of the bicentenaries of the independence of Latin American countries have given a reason to value the concepts which the region developed during its anticolonial struggle, the first of its kind in the world and at the dawn of capitalism. G. W. F. Hegel always perceived Latin America as an "echo of a foreign Life". He never understood nor visited Latin America. He could not understand that another "spirit of the people" existed here which did not have a place in his elaborate universal history. And as has happened in the past, today Latin America is once again a pioneering region when it comes to setting the foundations for what should become its second independence, an idea which has been revived by the Latin American governments associated with the New Left.
\end{abstract}

\section{Keywords}

Revolution of Quito, Congress of Vienna, independence of Latin America, second independence, spirit of the people

The Revolution of Quito (1808-1812) in many aspects pioneered the way during the Latin American independence process. Latin America is not mentioned in the Lectures on the Philosophy of World History (1837). For its author, the German philosopher G. W. F. Hegel (1770-1831), while developing a historical and even geographical description of America as a continent and Latin America, as an integral part of it, considered it as not part of "universal history". The "universal spirit" has no reason to be here. America belongs to prehistory, to before history, as according to Hegel, the geography imposes itself on man and he, as he cannot control it, has not been able to reach "consciousness of his own freedom" or, in other words, "self-consciousness" of his own spirit.

Furthermore, as "true" history only exists for Hegel when there is a state, Latin America is again

\footnotetext{
aPontifical Catholic University of Ecuador, Ecuador

Correspondent Author:

Juan J. Paz-y-Miño Cepeda, El Día N37-215, Edif. Carolofts, 2, Quito, Ecuador

E-mail: juan@pazymino.com
} 
excluded. It is important to remember that, according to Hegel, the state is defined as the structure that is capable of implementing and consolidating the measure of freedom that the spirit conquers. Therefore, and although North America (The United States of America) is a state, it is not the one Hegel has in mind. In the North American case, the state is only a mechanism to protect private property. Moreover, it embodies the protestant ethic.

America, in any case, has not yet finished forming itself. Consequently, what occurs here is still an "echo" of the Old World, a reflection of "foreign Life". But despite his Eurocentric vision, even Hegel was capable of noticing, with enough insight, that "In the future, the historic importance of America will appear, perhaps in the struggle between North America and South America" (Hegel 1980: 169-177; Paz y Miño 1998). This perceptive vision, however, is a poor description of what Latin America would live through. In contrast, the Liberator Simon Bolívar (1783-1830), Hegel's contemporary, assessed very well but on the other side of the Atlantic what was going to happen. His convincing statement has marked our history: "It seems that the United States is destined by Providence to infest America with miseries in the name of freedom" (Bolívar 1982: 261).

Hegel, of course, did not have any idea about Latin America. It is not possible to blame him for this. However, his Euro-centric vision has remained for a long time, with new and old nuances, and is used when looking at the progress of Latin American societies, nowadays or in their past.

Much has happened in the discussion about the independence of Latin America. What normally occurs (and this should not be understood as an accusation, revenge, or complaint to Europeans as a people) is that in Europe, the history of our region is unknown. Moreover, the idea that is not grasped with sufficient depth is that we have come to use different concepts even though the words we use are the same.

\section{BICENTENARY COMMITTEES}

Practically, all countries of our Latin America celebrated the bicentenary of independence between 2008 and 2012, though at different rhythms. The preparations started years back and became focused in 2007 when the ministers of culture met in Valparaíso (Chile), and agreed on the commemoration of the bicentenary of the independence of Latin American countries as well as to form the Bicentenary Group (Ministers of Culture 1998). Under these auspices, the governments formed their respective committees (Venezuela 1999; México 1999; Chile 1999; Ecuador 1999; Colombia 1999): Chile in 2000; Bolivia in 2003; Argentina in 2005; Colombia in 2008; Paraguay in 2008; Mexico in 2008; Venezuela in 2008; Ecuador in 2008. In 2007, even Spain created the National Committee for the Commemoration of the Bicentenaries of the independence of the Ibero-American Republics. The Bicentenary Group was eventually made up of 10 countries as El Salvador joined those mentioned above. Brazil also participated in some meetings (Bicentenary Group 2010). In 2009, the Alianza Bolivariana para los Pueblos de Nuestra América (Bolivarian Alliance for the Peoples of Our America-ALBA)-Bicentenary Group [Alianza Bolivariana para los Pueblos de Nuestra América (Bolivarian Alliance for the Peoples of Our America) [ALBA] 2010b] was formed but this organization did not have the same impact as the Bicentenary Group.

The Bicentenary Committees were responsible for the management and coordination of the different action plans. They were assisted by international institutions [UNESCO (United Nations Educational, Scientific, and Cultural Organization), UNDP (United Nations Development Program), OAS (Organization of American States), Mercosur-Cultural, Latin Union, SEGIB (Ibero-American General Secretariat), OEI (Organization of Ibero-American States), OIJ (Ibero-American Youth Organization)] as well as by multiple institutions and people in each country. 
This governmental and institutional framework was accompanied by events and programs which other public and private institutions had organized to celebrate the bicentenary. But, above all, all the activities offered and organized by people, organizations, neighborhoods, and the popular sectors that are a variety of agents within civil society, should be mentioned.

Therefore, Latin America had its own celebration of the bicentenary of independence in each country with a great variety of events and programs which were often covered by the media. The arts flourished: song, music, sculpture, painting, theater, and dance. Works of historical research were disseminated; dance events, parades, and performances were organized; museums, churches, convents, and craft centers were opened; public works, statues, and monuments were constructed; the population, overflowing with joy, passion, historic identity, with a feeling of national belonging and social and Latin American pride was mobilized.

It is a fact that in Latin America, in contrast to what is happening in Europe and other regions of the world, we do celebrate civic dates, we do hoist flags and sing anthems, we organize music festivals and become excited by the participation of the crowds, because these are the characteristics of our identity. And we will not change and, also, there is no need to change.

Nevertheless, from a historical and academic perspective, we Latin Americans have had important reasons to celebrate the bicentenary of our independence as it was not only an epic achievement of glories by leaders and patriots, it was also a revolution in terms of the wide popular participation which has a unique significance for the history of humankind. This Hegel never understood.

The conceptual differences between Latin America and Europe - or at least Spain-became already apparent when the Bicentenary Group was formed. It is not a breach of trust to talk about this. It is also not a reason for good relationships to be marred. But it is a fact that the representatives of some Spanish institutions, which participated in the meetings between 2008 and 2009, insisted, although only at the beginning that a grand commemoration of the bicentenary in all of Hispanic America was necessary. Consequently, a sole Ibero-American Bicentenary Committee should be formed.

At that time, the author was in charge of the Executive Presidential Secretariat for the Bicentenary in Ecuador, formed in accordance with Decree Number 1023 on April 15, 2008, by the President, Rafael Correa (2007-present). Therefore, the author participated in the meetings of the Bicentenary Group. As a historian, he was convinced that the bicentenary was a celebration which belonged to Latin America. This idea was also shared by the representatives of Bolivia, Chile, and Venezuela. Therefore, with this common vision, an agreement was reached against the formation of an Ibero-American Committee and in favor of only one committee - the Bicentenary Group. Furthermore, Spain officially adopted a much more appropriate diplomatic concept as it agreed to accompany the Latin Americans during their bicentenary festivities.

Beyond that fact, it can be seen that on this side of the Atlantic, we questioned two concepts deeply: On the one hand, we do not identify with Ibero-America nor with Hispanic America but with Latin America. One could say that this term does not correspond to our reality and, therefore, is wrong. But this does not matter to us as we have already turned it into the concept which best defines us and, as a consequence, we call ourselves Latin Americans and belonging to our Latin America.

On the other hand, we did not just simply talk about a celebration of past events but we knew how to assess a very decisive concept: What we commemorate is the bicentenary of the process of independence of Latin America. This means that contrary to Hegel's thinking, we had full 
consciousness in our region of the spirit we were moved by. In other words, we struggled in order to finish with colonialism in its Ibero version.

\section{THE REVOLUTION OF QUITO}

From the perspective of this anticolonial struggle, the Revolution of Quito, which happened between 1808 and 1812, can help us to understand a number of characteristics which nurtured the idea of independence that built Latin America.

The Revolution of Quito had different moments (Paz y Miño 2014): At Christmas 1808, a group of patriots met to discuss what actions to take in the country, which in those days was called Royal Audience of Quito (Real Audiencia de Quito), and against the local authorities as the events occurring in Spain had become known: Napoleon had dethroned the king, he had thrown him into prison and he had even appointed his brother as the new monarch. It was a conspiratorial meeting as they decided to depose the president Manuel Urriez Conde Ruiz de Castilla and set up a Supreme Government Junta, similar to the ones that had emerged in Spain itself.

However, the conspiracy had to wait as it was quickly discovered. Nevertheless, the meetings continued so that once everything had been prepared they deposed the President of the Audiencia on August 10, 1809, and a Sovereign Junta was appointed, presided over by Juan Pío Montúfar, Marqués de Selva Alegre. Montúfar pledged loyalty to Ferdinand VII, who was imprisoned in Bayonne. But the Junta did not receive a favorable response despite calling on other regions of the country to join. Quite to the contrary, troops were assembled to subdue those in Quito who had revolted and to support the royal troops sent from Lima. Faced with this imminent danger, the Junta surrendered and Ruiz de Castilla was restored to his office.

The restored president imprisoned the most important members and contributors of the Junta once the royalist troops from Lima had arrived in Quito, despite his promises of peace and not to persecute the patriots. An attempt to liberate the leaders provoked their killing on August 2, 1810, by the royalist troops in the barracks where they were kept. Moreover, the troops also attacked the neighborhoods in Quito which had supported the leaders of the Junta and murdered around 300 people. This was a real tragedy for the small capital of the Audiencia.

In order to calm down the situation, the arrival of a new Royal Commissioner, Carlos Montúfar, was necessary. He was, by coincidence, the son of the person who was going to be the President of the Junta of 1809. Together with him, a second Junta was organized. In December 1811, they even called a Congress of Deputies which on the 11th of that month recognized independence before the Regency Council.

Finally, on February 15, 1812, the Congress of Deputies with its members from Quito drew up a Constitution, the first in the history of Ecuador. This Constitution established the State of Quito with a clear republican structure as it had executive, legislative, judicial, and military power (Ecuador 2012).

It was Carlos Montúfar's reponsibility to head the armed defense of the State of Quito, but at the beginning of December 1812, the last revolutionary forces were defeated. The patriots had to flee or hide as the ones caught were sentenced, imprisoned, and some of them shot.

\section{THE HISTORICAL SIGNIFICANCE OF INDEPENDENCE}

After this short description, we can highlight some points to draw conclusions about history.

\section{First}

The Revolution of Quito seems to be an isolated case on this continent and audacious in its manoeuvre. Nevertheless, in 1804, Haiti had gained independence. And in the year 1809, itself, the rebellious uprisings of 
Chuquisaca and La Paz, present day Bolivia, took place. In 1810, the revolutions in Mexico, Caracas, Bogota, Santiago de Chile, and Buenos Aires broke out. In 1811, Asuncion and El Salvador followed. By 1812, Hispanic America had turned into a house on fire, even more so because Simón Bolívar was carrying out his liberating campaigns with unstoppable strength.

Starting from isolated and regional movements, the struggle for the independence of Latin America quickly acquired continental proportions. It is a fact that the most important leaders were criollos (people of Spanish descent but born in Latin America), distinguished intellectuals, politicians, and members of an elite that came from the dominant class. However, and using the words of Hegel, they were "instruments of history" as they were backed up by an impressive popular movement, something that often is forgotten. This movement took on a leading role by itself and joined the civil war which unleashed the struggle for emancipation.

Furthermore, it is also a fact that only the revolutions in Haiti and Mexico were carried out exclusively by popular force: in Haiti, the taking of power by mulattos and black slaves; in Mexico, the peasant and indigenous rebellion. Haiti was isolated by all; in Mexico, the Spanish and criollos put an end to the rebellion. As a consequence, their independence, in contrast to what happened in South America, was delayed.

With time and the deepening of the wars of independence, the seemingly isolated revolutions had turned into a general process. The combatants in the Battle of Pichincha, which finally, on May 24, gave independence to Ecuador, were Venezuelans, Columbians, Peruvians, Bolivians, Argentinians, and Chileans. There were even some English and German officers. And the Battles of Junín and Ayacucho in 1824, which brought the liberation of Latin America to a closure, were the same.

Therefore, independence was a process of accumulation of social forces based on the same "spirit": that of countries that wanted to be actors within their own history and that threw themselves into a struggle which was intended to eliminate the colonial government. In this process of struggles for independence, which lasted at least 16 years, the ideal of unity was consolidated, an ideal that is still characteristic of Latin American countries. This ideal is also based on what Simón Bolívar was planning in his days when he formed the Republic of Columbia (Gran Colombia): the unity of the region, even with the exclusion of the United States of America. Hegel could never know of, and what is even worse, understand this new spirit in his universal history.

\section{Second}

As a historic process, the independence of Latin America had also distinct stages. As occurred in Quito, at the beginning, all Juntas that were set up between 1809 and 1811 were loyalist or proclaimed their loyalty to Ferdinand VII. It is also not correct to confuse this process of independence with the process that started with the founding of the new Latin American Republics. Another characteristic was added to this definition: the disapproval with which they reacted to the French, who were seen, due to Napoleon's deeds, as the usurpers of the world. A decade later and under different circumstances, the Revolution of Guayaquil, which was declared on October 9, 1820, initiated the second and final phase of Ecuadorian emancipation.

Nevertheless, loyalty and anti-French sentiment, which were ideological components of the first Juntas, were not the main and essential characteristics of the intellectual mobilization within the pro-independence process.

The patriots mobilized other concepts which acquired a full revolutionary meaning. They talked about popular sovereignty and maintained the idea that with the King in prison, the common people regained this sovereignty. With this, the idea that the 
monarch was the absolute sovereign was definitely inverted. The Junta of Quito, as others in South America, acclaimed the representation of the countries and established in that way another principle of political life which is typical for representative democracies. Autonomy was accepted by the same governments which were mentioned in the Juntas that were set up. Therefore, the preceding revolutions of 1809 and 1810 marked the beginning of the independence process which would reach its peak only a decade later. And we are talking here about a process, as this was the historic movement of those days. In 1811, Venezuela was the first country to declare independence which was a new and definitely mobilizing concept; once this had reached Quito in 1812, it caused the drawing up of a Constitution and the founding of an ephemeral State of Quito. With this, the concepts of republicanism, democracy, constitutionalism, human rights, freedom, and sovereign state acquired their full meaning.

One could argue that all these were bourgeois concepts which had appeared at the beginning of European capitalism and had been introduced as the banner of the new class by the French Revolution. So it would seem that Hegel was, after all, right when he maintained the idea that we were an "echo of a foreign life". Of course, the influence of revolutionary bourgeois thinking in America cannot be denied. However, these concepts acquired their own dimension and contents in our Latin America. The same words were used but with other historic content. While in Europe, these concepts served to help capitalism, in this region of the world, they were used to gain independence from European capitalism, to integrate Latin America under one spirit and historic identity, and to guide the construction of the future Latin American republics. And this actually did happen since on this side of the Atlantic, there was not one single country that, once it had reached independence, kept or established a monarchical regime or even a constitutional monarchy as happened in Europe.

\section{Third}

The revolutions of independence in Latin America share in essence one characteristic which is not always emphasized enough; they are revolutions against colonialism and they took place at the dawn of the capitalist regime.

Indeed, the process the region lived through 200 years ago coincides with the era of the consolidation of capitalism in the world. This caused many changes on the different continents. Europe passed from the ancient regime to the bourgeois regime. The entire European culture, which had undergone a transformation process since the Renaissance, experienced true revolutions in daily life and university life as the ideas of rational humanism, positivism, enlightenment, scientism, and liberalism were disseminated. The European economy was transformed with the growth of industrialization, the use of machinery, and paid labor. The absolute monarchies and the empires fell into a crisis; republican principles such as the ideas of democracy, freedom, citizenship, and human rights progressively gained ground. Finally, national states were formed. The revolutions did not only occur in the Old Western Europe with France in the lead (1789), but also as the historian Jacques Solé has emphasized, in the Russian empire, Ireland, the Netherlands, Switzerland, in the Czech, Romanian, Polish, Hungarian, Greek and Italian areas and the British Isles and, of course, in America (Solé 2008).

In Latin America, the colonial regime started to be questioned. And this became manifest in all areas of social life: in cultural life, through the spread of enlightenment thinking, the scientific missions, the assessment of nature, the extent of positivism and rationalism; in the economy with reforms in foreign trade and the taxation system; the consolidation of the country estates, haciendas/fazendas or large farms or with the change in labor relations due to the abolition 
of the encomienda (area of land and its native inhabitants given to a conqueror or colonizer), the restrictions on the mita (forced labor of the indigenous population) and regulations on servile work. But the change was seen most in political life with the change in the relationship between the viceroyalties and the authorities of the Audiencia in opposition to the town councils. There was also a sudden increase in popular movements against domination and the authorities due to the accumulated reactions of the criollos against metropolitan power and the expansion of the principles of sovereignty, autonomy, or republicanism.

At the beginning of the capitalist system, the revolution of independence in Latin America inaugurated the era of anticolonial struggles all over the world. The countries in Asia and Africa unleashed struggles to break colonial ties but only reached their own independence well into the twentieth century.

Therefore, independence was a historical process which was not only important for this region or the American continent but for the entire world. Thanks to independence, the relationship that had implied a double track in the construction of contemporary societies was broken: Europe, at that point at the height of the mercantile era, could carry out those processes of "primitive and originary accumulation" of capitals, which Karl Marx (Marx 1973) examined with so much lucidity. Latin America, however, was not a mercantile society at that time but a colonial region. And it was this situation which for a long time had left a mark on a number of structures and which the Latin American countries would have to confront the moment they became republics.

With what the author has observed, he does not want to return to the dated dependency theory although, as is well-known, this theory had a large influence on intellectual life in other decades. Likewise, its limitations became clear when the attempt was made to understand the specific internal realities of Latin America by applying this theory.
However, it is evident to any historical analyst that the independence of Latin America constituted a rupture with one of the most important international economic relationships for the process of accumulation: the colonial system. While capitalism was born and spread throughout the world, Latin America, due to its independence, inaugurated the era of the fight for sovereignty and freedom of its countries. This goal has been reached too late, only recently in the second half of the twentieth century, when the anticolonial struggles in Africa and Asia started, facing constant resistance by the colonial powers.

The colonial system inevitably caused constant social resistance. In those days, indigenous uprisings, independent settlements, and rebellions by the slaves, protests by the craftsmen, mobilizations by the mestizos, and seditions by the criollos were plentiful in all of Hispanic America. The eighteenth century can be summarized with a short review of well-known events: the uprising of Túpac Katari and his brothers (1780), that of José Gabriel Condorcanqui Túpac Amaru (1780), or the 10 large uprisings by the indigenous people during the Audiencia de Quito, which caused anxiety and questioned colonial domination, its authorities, and the criollo elite class; the mestizo rebellions in Asuncion (Paraguay), which lasted 14 years (1721-1735), as well as the comuneros (joint holders of a tenure of lands) of New Granada (Nueva Granada) (1781), or the Rebellion of the Quito neighborhoods (1765), organized by the popular classes and extending throughout the city. The people of Quito complained precisely about the bad government.

The Revolution of the Alcabalas in Quito, which happened as early as 1592 , is also interesting in order to understand the independence process at the beginning of the nineteenth century. This revolution, which happened practically two decades before the struggles for independence "even reached a point at which the people of Quito started to talk about a free 
native land, to think about and even seriously plan independence in order to break with Mother Spain", as the historian Camilo Destruge (1909: 14) well remembers.

With this background, there is no doubt that the phase of the Juntas inaugurated the stage of the real revolution for Latin American independence. The source of these Juntas was the invasion of Spain by Napoleon and the imprisonment of the king. This has led to the belief that the crisis of the Spanish monarchy or the Atlantic crisis were the cause for the independence of Hispanic America or at least explain it (Rodríguez 2006; Guerra 2010). It seems that Hegel once again relives, as the independence of Latin America seems to be nothing more than an "echo of foreign life".

Nevertheless, the history of our region is stubborn and persistent. The French Revolution (1789), the independence of the United States (1776), the interests of England in America, the interests of Napoleon in the same continent, the ambitions of Carlota Joaquina Teresa de Borbón to be recognized from Brazil as the legitimate heiress to the crown, the court intrigues within the Spanish monarchy as well as the imprisonment of the king were all events that mobilized, at different rhythms, the American criollo consciousness. The Bourbon reforms in the eighteenth century created the environment in which the need for independence incubated. The English historian John Lynch considers these reforms as an attempt to stop "the first emancipation of Hispanic America" (or "state of informal emancipation") as they secured the "second conquest of America" (Lynch 1985). But even these reforms could not hide the fact that in the end, it was the colonial situation itself that created the conditions for the rejection and desire to overcome this such long lasting regime. The Atlantic crisis only became the reason for the final criollo outburst, or to put it in metaphorical language, it was the last straw.

Moreover, enlightenment thinking consolidated the autonomist consciousness of the criollos in Quito even before the invasion by Napoleon; the defense of Buenos Aires against the attempts of an English invasion in 1806 and 1807 also nurtured the autonomy movement in that city; Francisco de Miranda tried to obtain the independence of Venezuela in 1806; and long before, in 1804, Haiti had become independent. Therefore, the monarchical crisis could only slightly aid the desires for independence in colonial Hispanic America and offer the perfect framework for its success even though the process had to last for several years. The first restoration of the old regime in Quito took place in December 1812 when the Revolution of Quito had been defeated by armed force and the last patriots were persecuted, had to flee or leave the country and some of them, once caught were killed.

The setting up of the Congress of Vienna in September 1814 was a purely European event. The king of Spain sent Pedro Gómez Labrador to this meeting as the representative of the Spanish nation but who played a humble and poor role (Lafuente 1889: 191). It was clear that the powers that decided which path Europe was going to take were England, Austria, France, and Russia.

The following year, the definite defeat of Napoleon and the forming of the Holy Alliance turned into the "third attempt of a Spanish conquest" of the Real Audiencia de Quito as well as of the entire Hispanic America. Here we are taking up again the idea of John Lynch. The Spanish monarchy tried hard to restore the old colonial regime but found itself in the middle of a Latin America which definitely fought for its complete independence.

The following text by a Spanish historian in 1889 illustrates the situation clearly:

The fire of the revolt had been spreading, wreaking havoc, and seizing those remote and extensive areas. Buenos Aires had emancipated itself completely from the metropolis; the banner of independence fluttered in Chile and in some large cities of Peru; Caracas held its ground with bleeding stubbornness; the civil war in New Spain was already on fire; and although the authority of our viceroyalties was obeyed 
with difficulty in some parts, in all other parts, there was the risk of losing it, if Spanish domination had not already been wiped out. And in this eagerness to impose obedience and to conserve or reestablish our domination, our poor resources were consumed and pitifully, but gloriously, the blood of the few troops that had been left after six years of fighting with the French was shed. (Lafuente 1889: 201)

\section{Fourth}

It is also not correct to confuse this process of independence with the process of construction of the new powers in the founding of the new Latin American republics. Or, in other words, that independence caused the end of the colonial era in Latin America. This single fact is the historic benefit obtained by the region based on a continental effort by leaders, patriots, heroes, caudillos and, above all, entire populations that sustained the struggle for emancipation with resources and people. Another issue is that in the new republics, the power of the landowning oligarchy, which derived from the hegemony of the criollo class in the slowly rising states (which was the segment of the population which would most benefit from independence) would outweigh other groups in national life. The new republics were still based on the continuity of human exploitation, social disregard and marginalization of citizens who belonged to the vast, popular majority and, specifically, the indigenous population.

The rupture with colonialism was the first historic step which had to be taken in order to take on the task of constructing the new republics.

From an economic viewpoint, the independence process in Latin America caused severe destruction of mining production, devastated agricultural resources, and took away force from productive work; the wars caused ruin in crops, the death of inhabitants, the closing of roads, cuts in the supply networks of products for local and regional markets, an increase in prices and speculation in products. Livestock, houses, and harvests were pillaged; the authorities imposed property confiscation and forced transfer of goods; the military and the caudillos acted as if they were the owners of the country, taking as much advantage as they could. Therefore, from a purely crematistic perspective, independence brought it with an economic crisis. It was not good business. However, if the leaders and patriots, together with the people they fought with side by side, had thought about the disastrous economic results, then independence would simply never have happened.

\section{CONCLUSIONS}

The people and countries from 200 years ago give an example to the present moment when it comes to the mobilization of the concepts of sovereignty, autonomy, democracy, constitutionalism, or freedom as supreme values which are also valid for present day Latin America.

And this last consideration is a unique prospect, specifically for our present day, Latin American reality as there are now various countries, with governments belonging to the New Left, that talk about the need to reach a second independence.

Let us quickly remember that in contemporary Latin America, the heritage of a very remote past and the serious consequences that the last decades of the twentieth century had for our societies, such as regional subordination to transnational globalization and the neoliberal model, merged. At the end of the twentieth century, our region lived through conditions of accumulation which only benefitted the minority of internal elites and transnational capital because the protective structures of life and work for large national majorities in each country systematically collapsed.

And, with this, it becomes clear why in Ecuador as well as other countries that are part of the family of our Latin America, we talk about the need to achieve the second independence in order to free our countries from oppression, inequality, and the shackles of their past. Then, we can build better democracies and better societies in which the policy of Good Living or Sumak 
Kawsay (Quichua word), as the Ecuadorian Constitution of 2008 proclaims, is the rule.

This new Latin American effort to achieve its second independence seems also not to be well understood outside of Latin America. But it is on this side of the Atlantic where once again, as 200 years ago, this new form of colonialism, which implies a subordination to the ideology of neoliberalism and, as a consequence, the domination of capital over the human beings of the world has started to be questioned again.

Projects to create a new society are being carried out in Ecuador, Bolivia, Nicaragua, and Venezuela and they are at the forefront in Latin America. Argentina, Brazil, and Uruguay are doing the same. New relationships are being established between Latin American countries themselves. In addition, diversifying international relations has become an objective in order to counteract the weight imperialist policies and diplomacy have had in the region. And all this clashes with internal and external visions, which cause resistance, tensions, and polarization. This is somehow similar to what occurred during the first independence.

There is a new "spirit of the people" that is being nurtured and developed in Latin America and which is gaining its place within universal history. Our region is turning its back on being an "echo of a foreign life" and is moving forward on its own feet and with a clear objective. Again, Hegel has still not understood Latin America. But this is another story to be written and told.

\section{References}

ALBA (Alianza Bolivariana para los Pueblos de Nuestra América) (Bolivarian Alliance for the Peoples of OurAmerica). 2010a. Constituent Act of the ALBA Committee to Commemorate the Bicentenary of the Beginning of the Revolution of Independence in Our America. Retrieved June 28, 2010 (http://www. alternativabolivariana.org/modules.php?name $=$ News\&file $=$ article\&sid=4599).

- 2010b. "Bolivian Alliance for the Peoples of Our America-Trade Agreement, ALBA-TCP." Presented at the Meeting I, January 16-17, Caracas; presented at the Meeting II, April 15-16, Caracas.

Bicentenary Group. 2010. Committee of the Bicentenary Group. Retrieved June 28, 2010 (http://www.grupobicentenario. org/).

Bolívar, S. 1982. Simón Bolivar: la vigencia de su pensamiento Selección y prólogo de Francisco Pividal (Simon Bolivar: The Validity of His Thought. Selection and Prolog of Francisco Pividal). Havana: Casa de las Américas.

Chile. 1999. Bicentenary Chile. Retrieved August, 1999 (http://www.gobiernodechile.cl).

Colombia. 1999. Unofficial News Site Related to 200 Years of Independence of Colombia and Latin America (1810-2010). Retrieved August, 1999 (http://www. albicentenario.com).

Committee. 2010. Committee of the Bicentenary Group. Retrieved June 28, 2010 (http://www.grupobicentenario. org).

Destruge, C. 1909. Controversia Histórica sobre la iniciativa de la Independencia Americana (Historical Controversy on the Initiative of American Independence). Guayaquil: Litografía e Imprenta Gutenberg de Uzcátegui y Cía.

Ecuador. 1999. Bicentenary Ecuador. Retrieved August, 1999 (http://www.ecuadorbicentenario.gov.ec).

- 2012. "Constitution of the State of Quito or Solemn Society and Union Pact Between the Provinces That Form the State of Quito." Presented at the National Assembly of the Republic of Ecuador, February 15, 1812, Quito.

Guerra, F.-X. 2010. Modernidad e independencias. Ensayos sobre las revoluciones hispánicas (Modernity and Independence. Essays on the Hispanic Revolutions). México: Editorial MAPFRE and Fondo de Cultura Económica.

Hegel, G. W. F. 1980. Lecciones sobre la Filosofia de la Historia Universal (Lectures on the Philosophy of World History). Madrid: Alianza Editorial.

Lafuente, M. 1889. Historia General de España. Desde los tiempos primitivos hasta la muerte de Fernando VII (General History of Spain. From the Earliest Times to the Death of Fernando VII). Barcelona: Montaner y Simon, Editores.

Lynch, J. 1985. Las Revoluciones Hispanoamericanas 1808-1826 (The Spanish American Revolutions 1808-1826). Barcelona: Editorial Ariel.

Marx, C. 1973. El Capital. Crítica de la Economía Politica (Capital: A Critique of Political Economy). México: Fondo de Cultura Económica.

México. 1999. Bicentenary Mexico. Retrieved August, 1999 
(http://www.bicentenario.gob.mx).

Ministers of Culture. 1998. Letter of Intent by the Ministers of Culture Related to the Joint Activities to Commemorate the Bicentenary. Retrieved December, 1998 (http://www. grupobicentenario.org/index.php?option=com_content\&vie $\mathrm{w}=$ article\&id=86\&Itemid=55).

Paz y Miño C., J. 1998. Hege-Marx: de la Filosofía de la Historia al Materialismo Histórico (Hegel-Marx: Philosophy of History to Historical Materialism). Quito: Editorial Universitaria de la Universidad Central del Ecuador.

-2014. Quito en el Bicentenario del proceso de la Independencia del Ecuador (Quito in the Bicentennial of the Independence of Ecuador Process). Quito: Editorial Abya Yala-PUCE-THE-ADHILAC.

Rodríguez, O. J. E. 2006. La Revolución Política durante la época de la Independencia. El Reino de Quito 1808-1822 (The Political Revolution During the Time of Independence. The Kingdom of Quito 1808-1822). Quito: Corporación Editora Nacional.

Solé, J. 2008. Las revoluciones de fin del siglo XVIII en
América y en Europa (The Revolutions of Late Eighteenth Century in America and Europe). México: Siglo XXI Editores.

Spain Committee. 2010. Bicentennial Committee of Spain. Retrieved (http://www.bicentenarios.gob.es/ Paginas/Home. aspx).

Spain Consortium. 2010. Bicentennial Consortium of Spain. Retrieved June 28, 2010 (http://www.bicentenario1812. com/index.cfm).

Venezuela. 1999. Bicentenary Venezuela. Retrieved August, 1999 (http://www.bicentenario.gob.ve).

\section{Bio}

Juan J. Paz-y-Miño Cepeda, Doctorof History, Professor of Economic History of Ecuador and Latin America, Pontifical Catholic University of Ecuador (PUCE); research fields: economic and social history of Ecuador and Latin America during the nineteenth and twentieth centuries, immediate history of Ecuador. 